\title{
Crisis as opportunity: International health work during the economic depression
}

\author{
Iris Borowy \\ Historical Institute, University of Rostock. \\ iris.borowy@uni-rostock.de
}

Dynamis

[0211-9536] 2008; 28: 29-51
Fecha de recepción: 30 de octubre de 2007

Fecha de aceptación: 14 de marzo de 2008

SUMMARY: 1.-Background. 2.-The League of Nations Health Organisation becomes involved. 2.1.-The psychological effects of unemployment. 2.2.-Colonization. 2.3.-Statistical methods. 2.4.-Ways to safeguard health in times of depression. 2.5.-Nutrition. 3.-Conclusions.

ABSTRACT: The economic depression of the 1930 s represented the most important economic and social crisis of its time. Surprisingly, its effect on health did not show in available morbidity and mortality rates. In 1932, the League of Nations Health Organisation embarked on a six-point program addressing statistical methods of measuring the effect and its influence on mental health and nutrition and establishing ways to safeguard public health through more efficient health systems. Some of these studies resulted in considerations of general relevance beyond crisis management. Unexpectedly, the crisis offered an opportunity to reconsider key concepts of individual and public health.

PALABRAS CLAVE: Depresión económica, Sociedad de Naciones, salud pública, nutrición, sistema sanitario.

KEYWORDS: Economic depression, League of Nations, public health, nutrition, health system.

\section{Background}

Conventional wisdom has it that during times of crisis, public health suffers. There are certainly examples to back this up. Jan Sundin has shown how at times of the breakdown of the economy and public order mortality rates in several countries have gone up ${ }^{1}$. Recently, this effect has been 
most drastically demonstrated in post-Soviet Russia ${ }^{2}$. But this correlation of crisis and deteriorating health does not appear to be universally true. In fact, crises can spark unexpected benefits. For parts of the population in Great Britain, health actually improved during World War II. Food rationing and diets with more vegetables and less meat decreased mortality rates in some groups, particularly among mothers and infants ${ }^{3}$. In a more recent example, the economic crisis of the 1990s in Cuba forced people to eat less and walk or cycle more and, in the process, led to a drastic decline in obesity-related mortality such as diabetes, coronary heart diseases and stroke. Delighted researchers considered the event «an opportunity for science» ${ }^{4}$. But, more important, it may have presented an opportunity for public health, or, more precisely, an opportunity to rethink lifestyle patterns and to develop strategies to reform them in ways more conducive to public health. For Cuba, this opportunity was clearly missed. As soon as the economy recovered, nutrition-related mortality returned to familiar «normal» high rates.

A compelling occasion to consider the relation between crisis and public health was the worldwide depression of the 1930s. In the face of the daily evidence of mass unemployment and widespread misery, it seemed self-evident that the depression was bound to have grave repercussions for public health, particularly since poverty struck in various ways. Loss of income restricted people's means to ensure healthful living, notably food. At the same time, institutions that supplied help in times of illness (health insurances, hospitals, private charities) also suffered from lack of resources. At the same time, decreased tax payments reduced national budgets, causing cuts in health budgets. Thus, at a time when individuals most needed support, public and private systems were least able to deliver it. But available evidence did not support this intuitively plausible correlation. Circumstances were further complicated by the inclination of authorities in

2. Gavrilova, Natalia S.; Semyonova, Victoria S.; Evdokushkina, Galina N. Mortality crisis in Russia: New health threats. Paper presented at the 2002 annual meeting of the Population Association of America, May 9-11, 2002. [cited 5 Oct 2007]. Available at: longevity-science.org/PAA2002-Russia.pdf; Shkolnikov, Vladimir et al. Mortality reversal in Russia: The story so far. Hygiea Internationalis. 2004; 4 (1): 29-80.

3. Zweiniger-Bargielowska, Ina. Austerity in Britain: Rationing, control and consumption, 19391955. Oxford: OUP; 2000.

4. Carroll, Rory. Economic crisis in 1990s boosted health of Cubans. The Guardian Weekly. 5 Oct 2007: 12 . 
power and among conservative interest groups to interpret or manipulate ambiguous data in ways that served their political agenda and minimised their responsibilities ${ }^{5}$. However, not all questions regarding the extent of health costs were politically motivated, and the available evidence perplexed even officials sincerely seeking to understand the situation. As bewildered health experts around the world failed to find discernible effects of the depression, they sought advice from a supposedly authoritative voice in the field, the League of Nations Health Organisation (LNHO).

Founded in 1921, the LNHO had developed into a formative player in the international health scene. Though it was younger than several similar institutions, such as the Pan-American Sanitary Bureau (PASB) or the Office International d'Hygiène Publique (OIHP) and though its resources never amounted to more than a fraction of those of the International Health Board/Division of the Rockefeller Foundation, its work engaged some of the foremost specialists in several fields and gained broad respect. Its work was directed by the Health Committee ( $\mathrm{HC}$ ), whose members, respected scientists or health officials, met once or twice a year for consultations. HC decisions were implemented by the Health Section, which formed part of the League secretariat and employed a small full-time staff.

Initially, LNHO activities focused on epidemiology, public health statistics and biological standardization. But driven by the Socialist sympathies of its dynamic Medical Director, Ludwik Rajchman, and by the general egalitarian belief-system of the League of Nations, the LNHO had a builtin disposition to consider questions of social medicine ${ }^{6}$. The depression therefore found a receptive environment, but initially it presented LNHO members with something of an embarrassment.

\section{The League of Nations Health Organisation becomes involved}

In summer 1932, the Health Section received a number of requests on the effect of the economic crisis on public, but really was as much at a loss to explain ongoing developments as anybody else. Medical Director Rajchman

\footnotetext{
5. Webster, Charles. Healthy or hungry thirties? History Workshop Journal. 1982; 13 (1): 110129.

6. Borowy, Iris. International social medicine between the wars. Positioning a volatile concept. Hygiea Internationalis. 2007; 6 (2): 13-35.
} 
felt it was an LNHO responsibility to be able to present «a carefully prepared and reasoned memorandum» to the following League Assembly ${ }^{7}$. But it proved exceedingly difficult to define what sort of effects the depression was having on public health or if, indeed, it had any effect at all. Available data, notable mortality rates, failed to deteriorate in ways that common sense dictated. In August 1932, a first LNHO report on The Economic Depression and Public Health, conceded that at present «no appreciable effect on the aggregate mortality rates» was evident ${ }^{8}$. However, it also emphasised the enormous scope of the problem, as unemployment directly or indirectly affected 50-60 million people worldwide and numerous people worked reduced hours and faced conditions that were only marginally better. The document concluded that these alarming numbers gave rise to concern about potential health risks in the countries most affected by the crisis. The discussions at the following $\mathrm{HC}$ meeting in October revealed profound confusion. A helpless participant noted: «From every country comes the same story-official statistics reveal a healthier state than ever. And yet the feeling that the crisis must have deleterious effects on health is general» ${ }^{9}$. Even more disconcerting, a report written by US Surgeon General Hugh Cumming described a positive development in recent mortality and morbidity data and commented that it was as yet unclear whether this positive trend was related to the depression ${ }^{10}$. The implicit hint that an economic depression might actually improve public health must have been alarming to all those interested in social improvement.

Presumably, existing data could be construed to mean that unemployment and poverty were healthful conditions and that consequently responsible governments should refrain from relief and anti-poverty programs or, worse, should deliberately keep the masses in poverty. Though nobody actually made specific recommendations to this effect, the fear must have added pressure to efforts to find explanations for the paradox, while available data called into question years of social medical thinking. How could a depression of unprecedented dimensions leave people's health seemingly untouched,

\footnotetext{
7. Rajchman to Newsholme, 28 June 1932, League of Nations Archive, Geneva (hereafter: LONA), R 5866/8A/37494/1409.

8. The economic depression and public health. Memorandum prepared by the Health Section, Quarterly Bulletin of the Health Organisation (hereafter: Bulletin) 1932; I: 428 and 132.

9. Boudreau to Strode (RF), 21 Oct 1932, LONA, R 5936/8A/39676/39674.

10. Cumming report, 7 Oct 1932, LONA, R 5936/8A/39675/39675.
} 
or, if it did not, how could the effects be determined? However, as people faced a potential crisis not only of public health but also of basic tenets of medical knowledge they also realized the opportunity to gain new insights into the determinants of public health and strategies to improve it.

For the LNHO, the situation was similarly a major challenge as well as a chance to gain stature. At the time, no other comparable institution was likely to provide tangible answers. The PASB and the OIHP were too focused on infectious diseases and too much governed by governmental interests (by the USA in the case of the PASB, France for the OIHP) to be able to engage in effective research in the field. The Rockefeller Foundation, though large and research-oriented, was committed to a different health paradigm, based on fighting specific diseases. If the LNHO as an organization could deliver in this situation, it could enhance its own prestige while being of service to humanity. Its staff rose to the occasion. By October 1932, Rajchman had already begun shaping diverse pieces of information into tentative research concepts. In his search for more meaningful signifiers of public health status than mortality data, he looked to recent studies by doctors and physiologists, particularly in Germany, which pointed to abnormal losses of weight, disturbed metabolism and mental disequilibrium among unemployed and their families. He speculated that relatively unobtrusive symptoms might precede more noticeable health effects of the depression, and defining early signs might offer a way forward. At the same time, he acknowledged existing considerations regarding the influence of the depression on nutrition, internal migration and public health systems ${ }^{11}$. After some discussion, the $\mathrm{HC}$ decided on a work program consisting of six subtopics:

1.- Statistical methods to study the effects of depression on public health;

2.- Ways to study individual nutrition;

3.- Ways of ensuring healthful nutrition on a reduced income;

4.- Ways to safeguard health by the co-ordination of the work of all available public and private public health institutions;

5.- The effect upon public health of the migration of unemployed from the cities to places with inadequate sanitary provisions;

11. Rajchman to Madsen, 27 August 1932, Archives de I'Institut Pasteur (hereafter: AIP), Paris, Fonds Rajchman. 
6.- The psychological effects of the depression ${ }^{12}$.

Collectively, these items provided an opportunity to gain crucial insight into some key questions of public health and into effective ways to protect and improve it. Although little noticed at the time, these questions already created a change of paradigm of LNHO work, away from gathering information on the prevalence of and therapies for existing diseases to ways of preventing disease. This point marked the shift from a focus on the determinants of disease to the determinants of health.

Work on these six foci took place in sub-committees that cooperated with international experts and institutions, notably the ILO. Initially, minimal cohesion was retained by a series of papers on various aspects of the effects of the depression on health, produced and distributed by the Health Section in Geneva, but increasingly, the various committees worked along their own separate ways. Some topics produced disappointingly few results while others grew and spread until their origins in the economic crisis were forgotten or no longer served as points of reference.

\subsection{The psychological effects of unemployment}

Relatively, the study the psychological effects of the depression, remained the least substantiated. A small sub-committee had its first informal meeting in October 1932. Acknowledging the dearth of existing information, committee members developed a set of questions on which they hoped, largely through other $\mathrm{HC}$ members, to get information from various countries: the frequency or nature of mental diseases, hospital facilities and generally the psychology of - primarily young - unemployed. Both positive or negative effects should be considered, including the increase of free time as well as a loss of work discipline and possible rise in crime. However, the group confessed confusion about suitable methods to research the issue. The members did not expect to get useful material from national governments but, instead, vaguely hoped to find unpublished material in private

12. Work of the Health Committee during its nineteenth session, held Oct 10-15, 1932. C.725. M.344.1932. Official Journal of the League of Nations. Feb 1933: 354-355. 
companies or other institutions ${ }^{13}$. Perhaps inevitably, given this modest, unsystematic approach, results remained meagre. Some French responses to the questions painted an ambivalent picture. While the authors, apparently doctors or health officials, conceded that the crisis appeared to have resulted in a certain increase in cases of depression, alcoholism and possibly violence, the overriding impression was that it was less than could be expected and that the economic situation was, at best, a contributory factor, affecting those already pre-disposed towards mental instability ${ }^{14}$. Few other studies, if any, appear to have arrived in Geneva, despite repeated calls for them ${ }^{15}$. In stark contrast to the other topics, no report was ever published by the LNHO, neither as summary nor as reprint of individual papers. This lacklustre output appears remarkable. After all, possible analytic tools were in place, some thirty-five years after the publication of Émile Durkheim's ground-breaking work on suicide in which he linked the phenomenon to structural conditions of society ${ }^{16}$. Indeed, some information of this kind was clearly available to the group, since a closer look at Cumming's otherwise cheerful data, mentioned above, reveals suicide to be one of the few causes of death that had increased ${ }^{17}$. Similarly, it seems strange that LNHO staff and co-workers should have ignored or remained unaware of the groundbreaking study by Jahoda/Lazarsfeld/Zeisel on the long-term psychological and sociological effects of unemployment at Marienthal ${ }^{18}$. Maybe the members of the working group were overly impressed by the political sensitivity of the issue. At a time of intense nationalism and increasing international tension, authorities anywhere may have been reluctant to support studies

13. Influence of the economic crisis on mental health, C.H. 1112. 1 Nov 1932. LONA, Geneva, R 5936/8A/39785/39785; cf. The effects of the depression on hygiene in matters of mental health, C.H./C.E. 6. 10 Nov 1932. LONA, R 6050/8A/891/891.

14. Copies of report by Professor Laignel-Lavastine, H. Claude, M. Lévy-Valensi and Dr. Logre, positions unknown, between Dec 1932 and Feb 1933. LONA, R 6050/8A/891/891.

15. See letters from Humbert to Hamel and Pittaluga, 7 Jan 1933, and Bernard, 22 Sept 1933. All in LONA, R 6050/8A/891/891.

16. See e.g. Mäkinen, Illkka Henrik. The importance of culture for suicide mortality: A discussion of Durkheim and Parsons. In: Mäkinen, Ilkka H. On suicide in European countries. Collection of papers in lieu of doctoral thesis. Stockholm: Almqvist \& Wiksell International; 1997: Paper 4.

17. Cumming report, 7 Oct 1932. LONA, R 5936/8A/39675/39675.

18. See Jahoda, Marie; Lazarsfeld, Paul F.; Zeisel, Hans. Die Arbeitslosen von Marienthal. Österreichische wirtschaftspsychologische Forschungsstelle. Leipzig: Hirzel. 1933. No reference to this study has been found among LNHO sources and the authors do not appear in its bibliography, that constituted Bulletin. 1945; XI. 
into mental instability in their populations, too easily interpreted as a lack of military preparedness. This connotation may explain why this topic was the first on which German collaboration was suspended after the rise to power of the National-Socialist Party ${ }^{19}$. Maybe the dominance of eugenic paradigms in psychology was an impeding factor. Maybe, in more banal terms, it was primarily the absence of an energetic and inspiring chair of the sub-committee that accounted for the lack of more fruitful work. At any rate, the LNHO missed an opportunity to get involved in the entire field of psychosomatic factors of health.

\subsection{Colonization}

A similarly restricted outcome resulted from work on the migration of unemployed to the outskirts of cities, a process known as «colonization». In some instances, this process had led to squatter settlements along suburban rims. Apparently inspired by the ideas of garden cities, authorities in several countries began organizing these settlements into state supported communities. The main idea was to supply them with a small garden on which they could grow some vegetables and possibly keep some small livestock to supplement their family meals ${ }^{20}$. Reports from Germany, Scandinavia and, to a lesser extent, from the United States produced a diverse picture. Calculations in Germany estimated that an «industrious and capable settler» could earn about RM 300-500 in kind per year, i.e. roughly a quarter of the income of the average workman. But clearly it was a problematic solution whose success depended on a careful selection of settlers and was best with part-time workers ${ }^{21}$. A municipal and less widely distributed report revealed that the families in these programs were indeed better fed than those without such resources but they also suffered from insufficient sanitary provisions, especially in wild, unorganized settlements. In official settlements, a certain financial investment of the recipient unemployed was

19. Hamel to Olsen, 1 Feb 1933; and Reiter to Olsen, 10 Oct 1933. Both LONA, R 6050/8A/891/891.

20. Settlements on the outskirts of cities: their relation to the public health, LONA, C.H./C.E./5. 10 Nov 1932.

21. Friedrich Schmidt, Ministry of Labour. Suburban settlements for unemployed in Germany. Bulletin. 1934; III: 618-619. 
deemed necessary to prevent a character of charity and also to, indeed, help finance the schemes. But even the most minimal input proved unaffordable to some, so that the projects tended to exclude the neediest, i.e. their original target group ${ }^{22}$. In some papers, scientific rigor was clearly compromised by a certain degree of romanticism, as the descriptions veered towards a general criticism of modern civilization ${ }^{23}$. Remarkably, while the LNHO was to engage in comprehensive studies on healthful housing some years later, at this point it limited its activities to recording national experiences. A sub-committee meeting was planned in early 1933 but apparently never took place ${ }^{24}$. Once again, the absence of an energetic personality seems to have stood in the way of more intensive involvement.

\subsection{Statistical methods}

At other times, the involvement of a highly dedicated and competent expert could be a mixed blessing. Emil Roesle, director of the department for medical statistics in the German Reichsgesundheitsamt, had long been fascinated by the idea of devising scientific ways to measure health. Recently, he had published an article in a German journal on a longitudinal health index as a means of measuring the health of the unemployed ${ }^{25}$. This approach served as a basis for all further discussions. Roesle emphasized that unreflected comparisons of the health of unemployed with that of employed would yield little insight since typically the groups under study had a high turnover of individuals and one would therefore compare different people in different situations at different times. The health effects of unemployment, however, would most probably be the result of a slow, gradual deterioration of nutrition and living conditions and consequently would only be visible in long-term observations. Therefore, a satisfactory method would require monitoring individuals or specific stable groups at

22. Report Stadtbauamt Frankfurt, Abteilung Gartenwesen, 10 Dec 1932. LONA, R 5936/8A/39677/39677.

23. See some phrasings in Settlements, n. 20, LONA; Also Lindhagen, Senator C. Stockholm garden settlements. Bulletin. 1934; III: 364-365.

24. Olsen to Muesmann, 5 Jan 1933. LONA, R 6058/8A/967/967.

25. Roesle, Emil E. Der Längsschnitt-Gesundheitsindex und seine Anwendung für die Gesundheitsstatistik der Erwerbslosen. Zeitschrift für Gesundheitsverwaltung und Gesundheitsfürsorge. 1932; 3 (20): 461-465. 
different points before and during a prolonged period of unemployment. Roesle's paper was disseminated as an LNHO document for comments and further suggestions and provoked a critical response. Corrado Gini, Roesle's colleague from Italy, doubted the suitability of morbidity statistics in this context. Instead, he advocated detailed studies on nutritional status ${ }^{26}$. Similarly, renowned English statistician, Major Greenwood, commented that the method was scientifically accurate but entirely impractical. Besides, he doubted the usefulness of the underlying question:

«Suppose they (the results) provide a complete statistical proof that long continued unemployment is prejudicial to health and even sort out exhaustively the various ways in which, directly or indirectly, it is thus prejudicial. The practical conclusion will be that the sooner unemployment is brought to an end, the better it will be for the world at large. Is there any man, woman or child living who wishes new evidence to establish such a truism?» ${ }^{27}$.

In addition, there were political reservations about the project. In April 1933, the British member of the HC, Sir George Buchanan, voiced concerns that the activist LNHO approach would encroach upon national prerogatives and warned that the LNHO should not make «it a policy to begin by establishing an international formula for national inquiries» ${ }^{28}$. His criticism reflected the unwillingness of his government to accept the social and economic basis of health ${ }^{29}$. But it was also an expression of deep-seated reservations regarding the general role of the LNHO. Buchanan expressed both his government's attitudes and his personal convictions when he explained in 1921: «[T]he League of Nations represents associated Governments and its activities depend first and last on the views and action of Governments... For international cooperation in health questions that do not require official or Government intervention and support a League of Nations machinery would offer little advantage» ${ }^{30}$. This attitude was diametrically opposed to Rajchman's. To Rajchman, improving world health

\footnotetext{
26. Gini to Olsen, 29 Dec 1932. LONA, R 6041/8A/884/549.

27. Greenwood to Buchanan, undated. LONA, R 6116/8A/13812/13812.

28. Some observations by Sir George Buchanan on the inquiries in progress regarding the effect of the economic crisis on public health. April 1933. LONA, R 6116/8A/13812/13812.

29. See Webster, n. 6.

30. Buchanan, George. An address on international organization and public health. The Lancet. February 1921: 415.
} 
was part of a grander scheme of uplifting the world and world society ${ }^{31}$. The issue transcended petty animosities between two men. Inevitably, the depression brought out a general clash of expectations: at a time of crisis, was an international health organisation supposed to serve the needs of governments or to strengthen people's claims to governmental services?

Temporarily, Buchanan's criticism became immaterial because progress in identifying statistical means to measure public health stalled anyway. Roesle's plans for a cooperative project turned out to be overly ambitious. He had wanted a meeting where every participant would present a methodology and explain its merits on the basis of a short-term survey to be conducted beforehand ${ }^{32}$. Two months later, plans for the project were reduced to a mere collection of papers, and only few ever arrived ${ }^{33}$. Eventually, it seems only studies commissioned by the US Public Health Service under the supervision of statistician Edgar Sydenstricker were considered sufficiently important to be published. Sydenstricker was then Director of Research of the Milbank Memorial Fund (MMF), which gave financial support to surveys on the effect of unemployment on morbidity and malnutrition and published their results in October $1933^{34}$. A study on 12,000 wage-earning families in three US cities compared the incidence of disease. Illness in unemployed families was about $40 \%$ higher than in families with at least one fully employed member. The group worst hit by illness was the one whose financial status had dropped from full to no employment after 1929. Their illness incidence was $60 \%$ higher than that of their former colleagues who had remained in full employment ${ }^{35}$. This finding came closest to defining the effect of the depression on health, effectively disproving potential speculations that ill health might have been the cause for rather than the effect of unemployment. Yet, the method was obviously flawed in that it relied entirely on self-reported data. Thus, the accuracy of the data depended on

31. See especially numerous proposals he authored during WWII. See collection in File: Projets, notes et rapports de L. Rajchman, 1942-43. RAJ. AIP. See also Balinska, Marta Aleksandra. Une vie pour I'humanitaire. Ludwik Rajchman 1881-1965. Paris: Editions la Découverte; 1995.

32. Olsen to Tixier, 25 Jan 1933. LONA, R 6041/8A/549/549.

33. Memo by Rajchman, 20 March 1933. LONA, R 6041/8A/2242/549.

34. Sydenstricker, Edgar, et al. Health and the depression. Reprint from the Quarterly Bulletin of the Milbank Memorial Fund. 1933; XI (4).

35. Perrott, G.St.J.; Collins Selwyn, D. A preliminary report upon a survey of wage-earning families in Birmingham, Detroit and Pittsburgh. Reprint from the Quarterly Bulletin of the Milbank Memorial Fund. 1933; XI (4). 
how well the interviewed person, usually the housewife, remembered family income and illnesses of the time before the depression. Nevertheless, this study remained the most fruitful attempt to answer the original question. Making clear that more than simple statistics were at stake, Sydenstricker pointed out that the findings, though preliminary, should «constitute a warning against the complacency fostered by too complete reliance upon so crude an index of health as the death rate, and against any relaxation in the maintenance of preventive and relief measures» ${ }^{36}$.

The political significance of the findings gains additional prominence in light of the further fate of the text. Some months after its publication in the Milbank Memorial Bulletin, a very similar text using these and some additional data was published in the LNHO Bulletin ${ }^{37}$. Interestingly, this time US Surgeon-General Cumming appeared as author, without any mention of Sydenstricker or any of the other contributors ${ }^{38}$. Much of the original publication remained the same, including the morbidity changes in families whose socio-economic status had deteriorated. But in marked contrast the text insisted that it was as yet impossible «to draw conclusions as to their broad implications» ${ }^{39}$. In another subtle change the data were combined with an unrelated und far less informative study on children from Hagerstown, which compared average height und weight of white school-children without, however, correlating results to economic development or status. Two of three conclusions at the end of the paper refer to no or only slight effects of the depression found in this second study. The third conclusion noted the increase in malnutrition in those children, whose families had suffered a marked reduction in socio-economic status but omitted references to the mitigating effect of relief work ${ }^{40}$. Together these alterations resulted in a far weaker assessment of the health effects of the depression, and certainly in a much diminished responsibility of public authority. This tenor was in line with Cumming's hands-off attitude towards public health policies. Thus, even in their limited form of collecting studies, LNHO ac-

36. Sydenstricker, Edgar. Health and the depression. Reprint from the Quarterly Bulletin of the Milbank Memorial Fund. 1933; XI (4): 9-10.

37. Greenville, SC, and Syracuse, NY, for the studies on morbidity, and Pittsburgh for the study on nutritional status among children.

38. Cumming, Hugh. Health and the economic depression in the United States of America. Bulletin. 1934; III: 32-48.

39. Cumming, n. 38, p. 43.

40. Cumming, n. 38, p. 48. 
tivities found themselves in the middle of ongoing controversies about the relative responsibilities of the individual and society for people's health and about the proper role of the state at times of crisis. Within LNHO circles, the original conclusions were retained. The Canadian rapporteur of the LNHO to the Second Assembly Committee commented:

«It is a fact, however, that in certain cities malnutrition is more prevalent in families whose annual income per capita has been appreciably reduced than in families whose income has not been changed, notwithstanding the united efforts of public assistance and charitable organization. These studies have been well worth while and, on the whole, reflect very favorable upon the public and voluntary assistance which has been forthcoming during the present economic depression» ${ }^{41}$.

Thus, the general role of the LNHO in this controversy of publications is open to interpretation. It can be seen as having helped draw attention to the importance of economic and social determinants of health by initiating the study. It can likewise be accused of complicity in obscuring what may be regarded as obvious political conclusions regarding the need for continued public relief schemes.

\subsection{Ways to safeguard health in times of depression}

No such ambiguity marred LNHO work in the question of how public health could be safeguarded in times of depression by improved coordination of existing services. Shortly after the HC meeting of October 1932, a small expert group of experts, delegates both of the LNHO and of the ILO, was formed under the chairmanship of the Frenchman, Georges CahenSalvador, who was then Conseiller d'État as well as Secretary-General and driving force of the Conseil National Économique, a French Governmental body which had been founded in 1925 specifically in order to study economic problems and present possible solutions to the government ${ }^{42}$. Thus, predictably, his focus was not so much on details of medical activities as

\footnotetext{
41. Work of the Health Organization between the fourteenth and fifteenth ordinary sessions of the assembly. LONA, A.39.1934.III. 21 Sept 1934, p. 2.

42. For brief notes on Cahen-Salvador's position, see Le Conseil d'Etat. [5 Oct 2007]. Available at: http://www.conseil-etat.fr/ce/histoi/index_hp_aj021.shtml. See also Chatriot, Alain. La démo-
} 
on ways to define solutions to social problems and to introduce them to policy-makers. A lengthy paper by Oberregierungsrat Franz Goldmann of the German Health Bureau served as initial point of reference. In his text on structural and financial considerations on health systems he emphatically argued against across-the-board cuts in health budgets at times of financial crisis. Instead, savings should be made by making intelligent and considered choices regarding priorities for specific programs and societal groups (e.g. children). In addition, he recommended an improved coordination of existing services by private and public medical, economic and social institutions to avoid cost-intensive duplications. Ideally, there should be one central coordinating body. Money could be saved by increased funding of preventive measures ${ }^{43}$. These principles were mostly welcomed by colleagues ${ }^{44}$. However, the representative of the ILO observed that Goldmann's recommendations addressed general long-term structural weaknesses rather than acute crisis management. Indeed, the two points proved difficult to separate, because, as a hand-written note on the edge of the paper pointed out, «any rational method» would be «permanently applicable» ${ }^{45}$. Thus, the discussions were of more far-reaching relevance than the wording of the $\mathrm{HC}$ resolution suggested, or, in other words, they were more important than planned. They were also not strictly the object of the $\mathrm{HC}$ mandate. The Czech representative, Winter, had some temporary qualms about going beyond the original $\mathrm{HC}$ task. But Medical Director, Rajchman, welcomed the general applicability of Goldmann's suggestions as an advantage. And Cahen-Salvador went even further and explicitly considered it a duty to broaden the mandate, arguing that sometimes crises forced governments and the public to be more receptive to new ideas than during normal times, which was a motor of human progress ${ }^{46}$. Therefore, a conference in mid-February 1933 discursed three points that considered but then went beyond the present crisis:

cratie sociale à la française. L'expérience du Conseil national économique 1924-1940. Paris: La Découverte; 2002.

43. Goldmann to Rajchman, 14 Dec 1932. LONA, R 5936/8A/39992/39992.

44. Boudreau to Jameson, 22 Dec 1932. LONA, R 5936/8A/39992/39992.

45. ILO Memo. Crise economique et santé publique. 27 Dec 1932.

LONA, R 5936/8A/39992/39992.

46. C.H./ C.E./ V.5, 5ème session. 18 Feb 1933. LONA, R 6041/8A/2589/549, 8. Rajchman to Maurette, 16 Jan 1933. LONA, R 6041/8A/549/549. 
a. An overview over the effect of the depression on public health in several countries;

b. general principles of rationalization (emergency programs, coordination bodies, efficient management of hospitals, insurances etc.),

c. specific examples for successful measures under b. from various countries ${ }^{47}$.

The meeting confirmed the complexity of the issue but also a broad consensus among the experts who had been invited. Andrija Stampar from Yugoslavia, reported grave cuts in health expenditures and emphasized the specific problems of agricultural countries. Arthur Jauniaux, ILO representative from Belgium, similarly painted a bleak picture of the severely fragmented and inadequate services in his country. Meanwhile, the German ILO delegate, Helmut Lehmann repeated the bewildering finding that there was almost an «epidemic of health» in Germany despite the dismal economic situation, and his French colleague Yung expressed his fury at finding food being destroyed while women and children were suffering under-consumption. Cahen-Salvador found remarkably little resistance when he urged that the results of the meeting be presented not only in the customary report but also in an appeal to public opinion.

Some ingenious solution had to be found to reconcile a respect for national specifics with general policy recommendations. Cahen-Salvador suggested that the committee would enunciate general principles, leaving it to national commission to adapt them to respective circumstances. Factual discussions centered on rationalizations for hospitals, improved training on hygiene, more emphasis on prevention, the control of drugs and prevention of charlatanism, and, above all, on an improved coordination of services. While theoretically all principles could apply to all countries, in reality strong central coordination favored centralized systems. Therefore, some members hesitated to embrace the concept of a central coordinating body, particularly the participants from Great Britain, where independent private health institutions played a vital role, and their colleague from Belgium, where healthcare and insurance largely followed autonomous 
religious or corporate lines ${ }^{48}$. But remarkably, in the end all agreed on a common text.

Shortly afterwards, the report appeared in the LNHO Bulletin ${ }^{49}$. The basic tenor had changed surprisingly little since Goldmann's paper half a year earlier. Citing examples from various countries, the text denounced the «anti-economic» lack of funds for disease prevention ${ }^{50}$. Likewise, it characterized as «neither rational nor complete nor economical» the existing uncoordinated healthcare systems, especially for poorer classes, that relied on varying combinations of sickness and invalidity insurance, public medical assistance and health services, private associations, and voluntary organization $^{51}$. For an international report on a politically sensitive issue like public health systems, the language was extraordinarily forthright. It unequivocally endorsed compulsory sickness insurance as «the most appropriate and rational method» under «the present economic and social conditions» and recommended the «horizontal and vertical integration» of a large number of institutions in order to abolish the needless co-existence of similar bodies and duplication of efforts. ${ }^{52}$ Not content with simply stating what seemed to them advantageous arrangements, in the end the report called for tangible action, such as «the immediate constitution of national planning committees (...) and, if need be, of regional or local committees to appraise the value of the public health services and to organize these services according to a general plan ${ }^{53}$. Specifically, it recommended enquiries to be carried out under the auspices of the LNHO and with ILO cooperation which, although they might not produce immediately applicable policy blue-prints, might «discover means of providing medical care for the people on organized and economical lines» ${ }^{54}$. Clearly, the objective was not merely to describe present realities and potential futures but to instigate change.

The experience of the depression had widely undermined confidence in the benefits of unregulated market forces, so that public and politicians

\footnotetext{
48. Minutes of Meeting of Expert Group, 5-6 May 1933. LONA, R 6058/8A/3087/938.

49. Report on the best methods of safeguarding the Public Health during the Depression. Bulletin. 1933; II: 286-332.

50. Report on the best method, n. 49, 293.

51. Report on the best method, n. 49, 294-5.

52. Report on the best method, n. 49, 301 and 320 .

53. Report on the best method, n. 49, 329-330.

54. Report on the best method, n. 49, 297.
} 
were indeed more receptive to concepts of planning than before ${ }^{55}$. This background may explain that for all its subversive potential for existing social systems the report was swiftly cleared by the HC Bureau. Thus, the text was published in June 1933, only four months after the first meeting of the expert commission. However, the same was not true for the appeal to public opinion, so dear to Cahen-Salvador's heart. On Buchanan's insistence it had to undergo further discussions at the $\mathrm{HC}$ meeting in October ${ }^{56}$. To some extent, this concern is surprising, since the appeal really did not contain any new material but simply summed up the conclusions and recommendations of the report. However, this type of appeal was unique in the history of the LNHO. It had not been tried before, nor would it be used again later. At the $\mathrm{HC}$ meeting, Buchanan vehemently attacked both the theses and the strategy of the expert committee:

«The experts had certainly done their best, but it was not, in his opinion, the business of an international conference of experts, who did not represent their Governments, to say how health administrations in different countries should be organized, reformed or rationalised. (...) He took exception to the recommendation of the experts that countries should set up national committees to rationalise their health services with co-ordination by the Health Organization, and, in general did not see much advantage in making the economic crisis a pretext for international action for the rationalization of all public services» ${ }^{57}$.

But his colleagues continued to see an opportunity, rather than a pretext. Unimpressed with Buchanan's familiar warnings of a perceived «supergovernment» the other $\mathrm{HC}$ members welcomed the study and expressed appreciation of its applicability beyond this narrow period of crisis ${ }^{58}$. However, these decisions may have masked more extensive reservations. In February 1934, one of the authors of the report, Frank Boudreau con-

55. Capet, Antoine. Plan Beveridge ou plan Churchill? Consensus et dissensus sur la Reconstruction. Revue Française de Civilization Britannique. 1996; 9 (1): 108-109.

56. Boudreau to Tixier, 19 May, 1933, LONA, R 6041/8A/549/549; Buchanan to Rajchman, 3 July 1933, LONA, R 6058/8A/937/938. The draft appeal, see: Les methods les plus aptes à sauvegarder la santé publique en temps de crise. Projet d'appel. Undated. LONA, R 6058/8A/3087/938.

57. Report to the Council on the work of the twentieth session of the HC held at Geneva Oct 27th to Nov 1st, 1922, C.652.M.312.1933.III, LONA. 9-10.

58. C.H.1130. Appeal to public opinion and general recommendations of the Conference. LONA, Dec 1933. 
gratulated Cahen-Salvador and himself on the end of a «long chapter» of their history. Recalling unnamed obstacles on their way, he insisted that Cahen-Salvador's skill, particularly in front of the HC, had brought about the successful outcome. As the report and appeal had been sent, he declared, there was no more to do than to wait whether they would be put to good use or be soon forgotten ${ }^{59}$,

Sadly, the record points rather towards the latter. In view of the ambitious goals, the response was ambivalent at best. National committees for an overview of the entire health system were, indeed, formed in Spain, Denmark and - surprisingly - England ${ }^{60}$. There was an enthusiastic reaction from the health inspector of Algeria, Antoine Lasnet, who considered this issue particularly important for non-European countries ${ }^{61}$. There is little indication, however, that any of the activities provoked extensive reorganizations or even reviews of national health systems. Reform-minded contemporaries like Bela Johan in Hungary soon regretted the lack of feedback on committee recommendations ${ }^{62}$.

\subsection{Nutrition}

The most lasting effect of the crisis on LNHO activities was doubtlessly in the field of nutrition. The two nutrition-related points of the agenda propelled nutrition from a tangible but somewhat amorphous presence on the international health scene to centre stage. These two questions, i.e. how to study individual nutrition and how to ensure healthy nutrition on a reduced income, snowballed into a plethora of more questions and studies, of which only the broad outlines can be described here.

That nutrition constituted a major problem at a time of mass unemployment was perceived as self-evident. Press reports singled out inadequate nutrition as supposedly the most immediate consequence of the depression ${ }^{63}$. In how far this was true was, however, a question of intuition rather than

59. Apparently the entire process was strewn with «obstacles». See Boudreau to Cahen Salvador, 14 February 1934, LONA, R 6058/8A/9180/938.

60. Boudreau to Cahen Salvador, n. 59.

61. Lasnet to Olsen, 28 April 1934. LONA, R 6058/8A/9180/938.

62. Report to the Council on the work of the twenty-first session of the HC. C.233.M.97.III, 7 June 1934. 11.

63. See The economic depression and public health, n.8. 
firm knowledge. In England, which had been at the forefront of nutrition research, malnutrition had for several years been perceived as a yardstick by which to measure the health status of the population, particularly children, and the quality of welfare in society. In the face of the depression, the issue now erupted into a battle of surveys and interpretations ${ }^{64}$. The first task, therefore, was to identify robust and reliable methods for measuring the nutrition status in different societies. A conference was organised in Berlin in December 1932 under the chairmanship of Professor Gorter, Director of the Children's Clinic of the University of Leyden. Emphasising the need for further studies, particularly large-scale projects covering at least 10,000 families or $10 \%$ of the population, the conference recommended simple methods for large surveys and more elaborate clinical criteria for smaller studies. No uniform method was prescribed, but several possibilities recommended, such as various combinations of indicators like weight, height, blood content of the skin, amount of subcutaneous fat, muscular development, and, for clinical examinations, nitrogen content of the urine, protein content of serum, and pulse after different activities ${ }^{65}$. Although this outcome was scientifically weak, the meeting appears to have had a stimulating effect, and during the following months enquiries were put into practice in Austria, Belgium, Germany, Hungary, the Netherlands, Poland, Yugoslavia and, with some changes, in the USA ${ }^{66}$.

To some extent these studies provided the scientific background for the second nutrition focus of the project on health during depression times, i.e., to provide guidelines for a healthy diet on a restricted budget. Initially, this topic appears to have enjoyed little status. No expert committee was formed and no conference called, instead the issue was left to the nutrition expert of the Health Section, Wallace Aykroyd. The concept that the public needed to be educated in this question had surfaced in several countries and reacted to the profound changes in nutritional knowledge

\footnotetext{
64. Webster, n. 6, 112-115. For general background see also Smith, David, ed. Nutrition in Britain: Science, scientists and politics in the twentieth century. London: Routledge; 1997.

65. The most suitable methods of detecting malnutrition due to the economic depression (Conference held at Berlin from December 5th to 7th, 1932). Bulletin. 1933; II: 116-129.

66. Report of the Health Organization for the period October 1932 to September 1933. Bulletin. 1933; Il: 532.
} 
in recent years, notably the discovery of vitamins ${ }^{67}$. As work progressed, it became increasingly clear that the issue combined scientific, social, economic and political facets into a complicated web of considerations. In his report, published in 1933, Aykroyd presented a brief summary of the contemporary understanding of nutritional needs and compared average and recommended diets from different countries for people living on a low income ${ }^{68}$. Comparisons between the cost of these diets and unemployment benefits revealed that in England, a family of parents with three children had to spend $63 \%$ of their unemployment allowance on food, and in Germany, a family consisting of a man, his wife and a child of ten year of age had to spend no less than $83 \%$ on food ${ }^{69}$. Even these numbers need to be viewed critically, since, as the example of England shows, national nutrition recommendation could be extremely meager ${ }^{70}$. Implicitly, these numbers confirmed earlier assumption that parts of the population were bound to be malnourished because they did not have the money to be anything else. However, these were the most extreme calculations, based on assumptions that were open to doubt, and did not represent the entire picture. In his assessment of the prospects of health education, Aykroyd obviously tried to retain a tone of balance and moderation. Citing a common concept of «maternal efficiency» he concluded that «even where comparatively low income levels are concerned education of mothers is theoretically capable of bringing about dietary amelioration» ${ }^{71}$. But the potential effectiveness of education clearly differed depending on social and cultural circumstances. Prospects were better in countries with a widespread understanding and appreciation of the scientific aspects of dietetics than in countries in which greater interest was taken «in the art of preparing food than in food values» ${ }^{72}$. And Aykroyd did not hesitate to make clear that these aspects paled in situations of dire economic hardship. In open criticism of inter-

67. See, for instance, various pamphlets distributed in the United States since 1931: Food at low cost; and Sherman, Henry. Emergency nutrition, both distributed by the American Child Health Association; Stiebeling, Hazel et al. The family's food at low cost and getting the most for your food money. Distributed jointly by the Bureau of Home Economics \& Extension Service of the US Dept of Agriculture. All 1931, LONA, R 6080/8A/2386/2386.

68. Aykroyd, Wallace R. Diet in relation to small incomes. Bulletin. 1933; II: 130-153.

69. Aykroyd, n. 68, 148 and 143 respectively.

70. See Webster, Charles. Health, welfare and unemployment during the depression. Past and Present. 1985; 109: 204-230.

71. Aykroyd, n. 68, 149-150.

72. Aykroyd, n. 68, 151. 
pretations that held the housewife solely responsible for the quality of food without reference to surrounding circumstances, he commented:

«Tact and skill are obviously needed in preparing propaganda with the object of improving the diet of the necessitous. Such propaganda may easily become insulting if it is directed at a population struggling to feed itself on a totally inadequate wage or allowance. Further, there is implied irony in urging the use of frugal if well-balanced diets in a world suffering from overproduction of food-stuffs» ${ }^{73}$.

This was only the beginning of continuing intense research and publication activities. Another voluminous report, published in 1935, approached the issue in a more comprehensive manner, discussing, among others, the nutritional needs of the human body for adults and children, food deficiency diseases, food supply and education on healthy nutrition ${ }^{74}$. This publication was ground-breaking in several ways. For the first time, an international publication compared the various dietary recommendations and standards as they had been presented by different researchers or governments, taking into account the state of knowledge about various nutrients, different ages, levels of activity, living conditions and «dietary types». At the same time, it placed these clinical data in its social context, adding the production, distribution and preservation of food to the picture as well as collective meals and the teaching of healthy nutrition by school teachers, field workers and medical professors. Thus, it was an unprecedented attempt to integrate physiological, scientific and economic factors into a comprehensive discussion of «Nutrition and Public Health» ${ }^{75}$.

After that, League nutrition work continued in two strands. The LNHO formed a «Technical Commission» that continued studies on physiological aspects. A more comprehensive approach was taken by a Mixed Commission, consisting of members of the LNHO, ILO, the International Agrarian Institute in Rome and the Financial and Economic Section of the League Secretariat. The Technical Committee was supposed to define questions «of practical importance» suitable for further international study and to

\footnotetext{
73. Aykroyd, n. 68, 150.

74. Burnet, Etienne; Aykroyd, Wallace. Nutrition and public health. Bulletin. 1935; IV: 232-474.

75. Burnet, Aykroyd, n. 74, 322-474.
} 
provide scientific background information to the Mixed Commission ${ }^{76}$. In that capacity, it defined its own standards on nutritional requirements of the human being between conception and old age ${ }^{77}$. Thus, it produced the first instance of international dietary standards. The text was potentially controversial, since the LNHO standards were tangibly higher than those of most national governments ${ }^{78}$.

The Mixed Commission turned out politically even more sensitive. Their final report, published and distributed widely in 1937, enunciated a number of political statements and demands ${ }^{79}$. Echoing Aykroyd's report of 1933, it stated that the quality of nutrition could be improved by improving knowledge and/or income. Improving knowledge was relatively the simpler task. All it needed was more research and an improved communication of the research findings through public education. Income was clearly more complicated. The text detailed that increased individual income could be achieved either through national economic growth or, if that was not possible (as it supposedly was not during a time of a economic crisis), the task necessitated a redistribution of wealth. The radicalism of this demand was slightly obscured but not really mitigated by a long list of practical suggestions to improve the economic side of nutrition: sufficiently high minimal wages; social regulations; school meals for needy or all children; application of scientific findings in state meals, a suitable trade policy which aimed at a maximization of affordable food rather than national self-sufficiency, or agricultural credits which allowed small farmers to invest ${ }^{80}$. Clearly by this time, the considerations were far removed from the original focus on crisis strategies. The recommendation no longer addressed short term economic difficulties but aimed at limiting economic disparity within populations and broad state responsibilities for the well-being of the individual person.

\footnotetext{
76. Report to the Council on the work of the twenty-second session of the Health Committee, C.426.M.218.1935.III, Oct 1935, 4.

77. See Report on the physiological basis of nutrition drawn up by the technical commission of the HC, C.H.1197. Bulletin. 1936; V: 391-416.

78. Weindling, Paul. The role of international organizations in setting nutritional standards in the 1920s and 1930s. In: Kamminga, Harmke; Cunningham, Andrew, eds. The science and culture of nutrition, 1840-1940. Amsterdam/Atlanta: Rodopi; 1995, p. 325 and 327.

79. The relation of nutrition to health, agriculture and economic policy. Final report of the mixed committee of the League of Nations, A.13.1937.II.A. Geneva 1937.

80. The relation of nutrition to health, n. 79. List of demands, 40.
} 
These goals could also be termed an egalitarian society and the welfare state, tangible as much as visionary objectives.

\section{Conclusions}

In retrospect, a lot of the original questions of agenda were not answered, not least among them whether the depression was generally harmful to public health. But for the LNHO as an institution, work on the economic crisis clearly represented a watershed. Before, it had spent a decade on an ever-increasing number of topics, that were impressive in their breadth but somewhat unsystematic, reflecting a rather arbitrary selection of interests based on who among $\mathrm{HC}$ members or of concerned governments would take the initiative of a proposal. Afterwards, LNHO work molded into a coherent program. Rather than studying a multitude of unrelated issues and diseases, work now addressed the requirements of health as common point of reference. Thus, the depression had strengthened the natural inclination of the people active at the LNHO by focusing attention on the social perspective of health, but admittedly also by curtailing funds, which forced the LNHO to bundle its declining resources. Concentrating on multi-faceted and broadly relevant issues such as rural hygiene and housing the LNHO developed a distinct profile that distinguished it from the other international health organizations of the time and with which it would leave its most lasting imprint. Notably, it developed a holistic understanding of health, not as a separate entity but as a quality that formed an integral part of all spheres of life. It was this all-encompassing view of health that fed into conceptualisations of the post-World War II health institution and its ideological foundation. These plans proved a formative influence on the WHO and its definition of health as «a state of complete physical, mental and social well-being and not merely the absence of disease or infirmity» ${ }^{81}$.

In terms of institutional international health, the economic crisis of the 1903 s provided an opportunity that was well taken.

81. WHO. Basic documents. Constitution. Available at: http://www.who.int/gb/bd/PDF/bd46/ebd46_p2.pdf 